\title{
Invited review: Are adaptations present to support dairy cattle productivity in warm climates?
}

\author{
A. Berman ${ }^{1}$ \\ Department of Animal Science, Hebrew University, Rehovot 76100, Israel
}

\begin{abstract}
Environmental heat stress, present during warm seasons and warm episodes, severely impairs dairy cattle performance, particularly in warmer climates. It is widely viewed that warm climate breeds (Zebu and Sanga cattle) are adapted to the climate in which they evolved. Such adaptations might be exploited for increasing cattle productivity in warm climates and decrease the effect of warm periods in cooler climates. The literature was reviewed for presence of such adaptations. Evidence is clear for resistance to ticks and tick-transmitted diseases in Zebu and Sanga breeds as well as for a possible development of resistance to ticks in additional breeds. Development of resistance to ticks demands time; hence, it needs to be balanced with potential use of insecticides or vaccination. The presumption of higher sweating rates in Zebu-derived breeds, based upon morphological differences in sweat glands between breeds, has not been substantiated. Relatively few studies have examined hair coat characteristics and their responses to seasonal heat, particularly in temperate climate breeds. Recently, a gene for slick hair coat has been observed that improved heat tolerance when introduced into temperate climate breeds. No solid evidence exists that hair coat in these lines is lighter than in well-fed warm climate-adapted Holsteins. Warm climate breeds and their F1 crosses share as dominant characteristics lower maintenance requirements and milk yields, and limited response to improved feeding and management. These characteristics are not adaptations to a feed-limited environment but are constitutive and useful in serving survival when feed is scarce and seasonal and high temperatures prevail. The negative relationship between milk yield and fertility present in temperate climates breeds also prevails in Zebu cattle. Fertility impairment by warm conditions might be counteracted in advanced farming systems by extra corporeal early embryo culture. In general, adaptations found in warm climate cattle
\end{abstract}

Received October 25, 2010.

Accepted January 20, 2011.

${ }^{1}$ Corresponding author: berman@agri.huji.ac.il breeds did not increase heat dissipation capacity, but rather diminished climate-induced strain by decreasing milk production. The negative relationship between reproductive efficiency and milk yield, although relatively low, also appears in Zebu cattle. This association, coupled with limited feed intake, acting over millennia, probably created the selection pressure for a low milk production in these breeds.

Key words: heat stress, adaptations, dairy productivity

\section{INTRODUCTION}

Environmental stress has a severe effect on the productivity of animals and, in particular, on that of dairy cattle. Environmental stress is a stumbling block for farming systems exposed to heat stress that are striving to increase animal productivity. The prospect of environmental stress is aggravated by present global warming accompanied by periods of extreme weather. The latter may have increasingly severe effects on welfare and productivity of cattle. Are certain breeds endowed with better capacities for maintaining productivity under environmental stress? The following review examines the available evidence for characteristics related to warm climate tolerance in dairy cattle.

A widely accepted notion which emerged in the mid 20th century holds that breeds endogenous to a warm climate are endowed with greater capacity for adaptation to the local environment in contrast to breeds of cattle endogenous to temperate climates (Wright, 1954). This idea is based on a large number of early studies in subtropical and tropical countries (West Indies, Philippines, Egypt, Jamaica, India, Cochin China, Cambodia, Malaysia, and East Africa) in which importing temperate zone breeds or backcrossing local breeds to temperate zone breeds was followed by regressive changes. It is noteworthy that animals were then maintained in the warm climates according to housing concepts from temperate regions and with limited knowledge of local diseases, nutrition in warm conditions, or physiological effects of high ambient temperatures.

The nature of adaptation of farm animals to warm climates has not been fully clarified. Adaptation might 
appear as constitutive characteristics that evolved in the course of evolution in a given environment and are generally expressed. Alternatively, adaptation might appear as a capacity for physiological responses that express mostly when environment stress is present.

The responses of cattle to warm conditions have been extensively explored in recent decades. This review examines whether adaptive characteristics for heat stress are present in warm climate breeds that might sustain animal performance in warm climates and warm weather periods.

Adaptive characteristics to warm climates encompass a wide range of physiological functions and morphological attributes. This review searched targets known to potentially affect animal performance in warm climates. These include adaptations to external parasites, attributes of heat exchange like evaporative and nonevaporative heat loss, and metabolic heat production. In addition, the disruption of reproductive functions by warm conditions draws attention to an effect of breed on early embryo sensitivity to heat stress. Not considered, in the effort to conserve space, are several important topics such as breed differences in feed utilization, endocrine function, and disruption of ovarian cyclicity and uterine function.

\section{ADAPTATIONS TO PARASITES}

In large parts of most continents, parasites may affect survival and performance of cattle. Parasites are present in variable densities in the environment surrounding animals, and the extent to which they infest animals differs between individuals and breeds. The reasons for these differences are not altogether clear. Ectoparasites may affect an animal directly (e.g., the damage inflicted by a multitude of ticks engorging on its blood). Additional, indirect effects may be present when the ectoparasites are vectors of diseases, like the anaplasmosis, babesiosis, and cowdriosis agents carried by ticks (Frisch et al., 2000; Kadarmideen et al., 2009.) or the trypanosome carried by the tsetse fly (Mattioli et al., 2000). Ticks are present in many geographical regions, whereas trypanosomiasis is limited to west and equatorial Africa.

Resistance to ticks is found, in some, but not all, Bos indicus cattle breeds of Asia and Australia (Bock et al., 1999) and resistance to the tsetse fly is found in the humpless Sanga cattle breeds of Africa (Fivaz et al., 1992). In such cases, genetic resistance that makes the animals' skin less attractive to the parasite may be critical. In addition to tick resistance, resistance to the tick-borne disease factor may vary between cattle types. Zebu (Sahiwal) cattle may also more resistant than European Bos taurus (Holstein) dairy breed calves to tick-borne Theileria annulata infection (Glass et al., 2005). Herds of B. indicus-cross cattle are still at risk of Babesia bovis infection induced by Boophilus microplus in environments where exposure to B. bovis is light in most years but occasionally high (Jonsson et al., 2008), suggesting resistance to disease is exposure dependent.

The acquisition of resistance to ticks in sensitive breeds by use of selection or breeding, if possible, may require years to attain. The matter is further complicated by indications that resistance to ticks may differ with the species of ticks and the breed of cattle (Mattioli et al., 2000) so that the acquisition of resistance to parasites may offer geographically-limited solutions. The feasibility of combining genetic resistance solutions, which require extended breeding programs, with chemical treatments adds complexity to the apparent simplicity of solutions to the parasite problem.

Vaccination against the disease causative agent carried by the ectoparasite is another path, though not applicable in all cases. Vaccination is effective against Theileria annulata (Rasulov et al., 2008), vaccination against B. bovis and Babesia bigemina provides sound, long-lasting protection, that against Anaplasma marginale only provides partial, variable protection (Bock and de Vos, 2001). In contrast, neither vaccination nor environmental management have yet been successful in preventing trypanosomiasis (Black et al., 2001).

In summary, significant genetic resistance to tick infestation and tick-induced diseases exists in some $B$. indicus breeds but it is not absolute and is not fully retained in crosses of Zebu breeds with cattle of temperate zone breeds. In extensive farming systems, selection for resistance to ticks may be an advantageous solution. In more intensive management and farming systems, the use of insecticides to decrease tick numbers might be a complementary solution.

\section{ADAPTATIONS TO HEAT STRESS}

Animal productivity is an output of metabolic processes for synthesis of milk, meat, and wool that all generate heat. Animal productivity may, therefore, be viewed as a heat exchange system, in which animals produce heat through their metabolism and exchange heat with the environment. All terrestrial farm animals are homeothermic species (i.e., they regulate their body temperature within a narrow range). Body temperature is regulated by modulation of metabolic heat production and heat loss from the body. Adaptations to environmental heat stress may involve metabolic heat, evolving in maintenance and production processes, as well as heat loss from the body. The heat generated in the body is used in the maintenance of body temperature, and amounts in excess of that required are dissipated 
to the environment by evaporative and non-evaporative pathways.

The evaporative path is represented by respiratory water loss and by evaporation of water brought to the skin surface by the sweat glands (i.e., sweating rate). Sweating rate depends on the density of sweat glands, their morphology, and water transfer capacity. Nonevaporative heat loss also occurs as heat transfer from the skin to the surrounding air and is largely determined by the skin-to-air temperature gradient, air flow near the body surface, incoming radiant heat, as well as hair coat characteristics. Breed differences in these characteristics may open perspectives for adaptations to warm climates by selection and breeding.

\section{Respiratory Water Loss}

Respiratory heat loss has been measured in most studies by the mask open circuit method. In almost all studies, respiratory heat loss has been underestimated because of rebreathing of expired air that creates the need to correct for the ratio of respiratory tidal volumeto-mask dead space (McLean, 1963). No sufficient data are, therefore, available for estimating breed differences.

\section{Sweat Gland Characteristics}

An overview of published data was carried out to examine the presumption that higher sweating rates prevail in breeds endogenous to warm climates. The characteristics of sweat glands in 5 European breeds (B. taurus), namely Ayrshire, Guernsey, Australian Illawarra Shorthorn, and Friesian, indicated breed differences in sweat gland volume, but not in density of sweat glands (Nay and Hayman, 1963). Zebu cattle had much more numerous glands of larger volume than did Shorthorn, Jersey, and Friesian cattle (Dowling, 1955; Nay and Hayman, 1956). It is not self-evident that such morphological differences between breeds also indicate functional differences. Rather, experimentallydetermined sweating rates are needed for breed comparisons.

No differences in sweating rate were found between Jersey and Jersey $\times$ Red Sindhi animals $($ McDowell et al., 1954). The Damascus breed is estimated as significantly related to the Zebu (Loftus et al., 1999). Yet, relationship to it (25 to $0.1 \%$ ) did not affect sweating rate in Holstein $\times$ Damascus (Berman, 1957). In Senepol cattle, a breed developed from West Africa N'Dama cattle, imported around 1800 to the Caribbean, sweating rate was less than $20 \mathrm{~g} \mathrm{~m}^{-2} \mathrm{~h}^{-1}$ (Olson et al., 2006). Higher sweating rates, about $100 \mathrm{~g} \mathrm{~m}^{-2} \mathrm{~h}^{-1}$, were reported for $25 \%$ Senepol: $75 \%$ Holstein cattle (Dikmen et al., 2008). Sweating rates of about 200 to $260 \mathrm{~g} \mathrm{~m}^{-2} \mathrm{~h}^{-1}$ were measured in hyperthermal Angus and Hereford steers (Vajrabukka and Thwaites, 1984; Scharf et al., 2008), in Hereford, Brahman, Boran (B. indicus), and Tuli steers (B. taurus) and their crossbreeds (Gaughan et al., 1999), Nellore (B. indicus) cattle (McManus et al., 2009), Hereford:Shorthorn and Brahman:Shorthorn steers (Schleger and Turner, 1965), as well as in lactating Holstein cows (Berman and Morag, 1971). In Jersey and Jersey $\times$ Guzerat crossbreeds, sweating rates were 240 and $400 \mathrm{~g} \mathrm{~m}^{-2} \mathrm{~h}^{-1}$, respectively (Hayman and Nay 1958). Sweating rates in Holstein and Gyr $\times$ Holstein crossbreds were similar, at about $350 \mathrm{~g} \mathrm{~m}^{-2} \mathrm{~h}^{-1}$ (Gebremedhin et al., 2010). In White Fulani (B. indicus) exposed to solar radiation, a sweating rate of $454 \mathrm{~g} \mathrm{~m}^{-2}$ $\mathrm{h}^{-1}$ was found in contrast to a value of $300 \mathrm{~g} \mathrm{~m}^{-2} \mathrm{~h}^{-1}$ for German cows (Egbunike et al., 1983). Higher sweating rates, of 480 and $540 \mathrm{~g} \mathrm{~m}^{-2} \mathrm{~h}^{-1}$ were measured in Gyr and Hariana (Joshi et al., 1968), and in Jersey and Sindhi $\times$ Jersey cows (Pan et al., 1969). Sweating rates in shaded Sahiwal and Sahiwal $\times$ Holstein crossbred heifers were 630 and $380 \mathrm{~g} \mathrm{~m}^{-2} \mathrm{~h}^{-1}$, respectively (Aggarwal and Upadhyay, 1997). Also noteworthy is the presence of large differences in sweating rate between B. taurus breeds exposed to heat stress (Scharf et al., 2010).

A comparison of sweating rates measured in different studies may be difficult. Sweating rates are related to ambient humidity, and in Holstein cows they varied from 300 to $50 \mathrm{~g} \mathrm{~m}^{-2} \mathrm{~h}^{-1}$ when ambient humidity increased from 30 to $75 \%$ (Maia et al., 2005). This does not apply, however, to cases in which breeds were compared within a study, as reported here. Further complexity to data interpretation was added by a study of the relationship between sweating rates and rectal and skin temperatures (Schleger and Turner, 1965), indicating that maximal sweating rates were similar in steers of British breeds (Hereford $\times$ Shorthorn) and Brahman $\times$ Shorthorn steers, but these were attained at lower rectal and skin temperatures in the latter animals. As a whole, however, no consistent evidence exists that breeds that evolved in warm climates (i.e., Zebu breeds and their crossbreeds) are endowed with higher sweating rates.

It is significant in this respect, that evaporation from a wetted hair coat exposed to 0.2 and $1 \mathrm{~m} / \mathrm{s}$ air velocity, indicative of maximal evaporation rate, was approximately 500 and $1,000 \mathrm{~g} \mathrm{~m}^{-2} \mathrm{~h}^{-1}$, respectively (Berman, 2008; Gebremedhin et al., 2010), markedly greater than those of most reported sweating rates. This result means that body surface wetting, supplemented by forced air flow to attain near maximal evaporation, may be used to reinforce heat dissipation from the body for heat stress relief, at least in the indoor-fed dairy farm systems (Flamenbaum et al., 1986; Berman, 2009). 
Under such conditions, genetic variation in sweating rate becomes less important.

\section{Hair Coat}

The effect of hair coat characteristics on adaptability to warm climates has been recently examined in depth (Berman, 2004; Olson et al., 2006). Hair coat thickness, along with hair weight per unit surface, is an important determinant of non-evaporative heat loss from the body surface (Bennett, 1964). A now classical study (Yeates, 1954), extended by later studies (Berman and Volcani, 1961; Hayman and Nay, 1961), showed that the hair coat is markedly affected by photoperiod, which modulates seasonal changes in hair coat (i.e., the shedding of the long heavy winter coat and its replacement by a thinner and lighter summer coat). It is significant that similar seasonal changes were also recorded at a low latitude of $22^{\circ}$ (Pinheiro and da Silva, 1998), as well as at the 32 to $34^{\circ}$ latitude in the 2 former studies. These results suggest that the greater changes in photoperiod amplitude at higher latitudes are not a strict limiting factor for induction of hair coat changes. Photoperiod, however, is not the only factor affecting hair coat. Warmer ambient conditions enhance the summer-type attributes of hair coat in Holstein cows (Berman and Volcani, 1961) and beef breeds (Schleger and Turner, 1960b). Exposure of cow to high temperatures at constant photoperiod caused similar changes in hair properties (Kibler et al., 1965). Photoperiod and temperature-induced changes in hair properties affect the ability to maintain thermal balance because hair coat characteristics are well correlated with skin and rectal temperatures, particularly so in B. taurus (Schleger and Turner, 1960b).

Nutrition also affects characteristics of the hair coat. Limiting nutrition induced the formation of a wintertype hair coat, which impaired heat tolerance (Yeates, 1956). In this context, it is suggestive that average Holstein cows in Brazil had markedly thicker and longer coats in summer and winter than well-fed Holsteins (Pinheiro and da Silva, 2000). Also, supplemental nutrition in beef cattle produced a much sleeker coat than that typical of similar animals at pasture (Schleger and Turner, 1960b). Interactions between the 3, namely photoperiod, temperature, and nutrition, play an important role in determining hair coat characteristics.

Breed differences in hair coat characteristics also are documented. Bos indicus (Red Sindhi and Sahiwal) had a shorter and lighter hair coat than their crosses with $B$. taurus beef and dairy breeds during all seasons of the year (Hayman and Nay, 1961). Mean coat thickness $(\sim 2.7 \mathrm{~mm})$ were similar in Gyr, Gyr $\times$ Holstein F1, and $>75 \%$ Holstein $\times$ Gyr (Verissimo et al., 2002). Lighter hair coats are not limited to $B$. indicus breeds, as this characteristics also is present in Senepol cattle, which are descendants of West African N'Dama (Olson et al., 2003), as well as in the Carora cattle, which are descendants of Iberian cattle mixed with indicine (Dani et al., 2008). The slick hair gene, that endows its carriers with a slick hair coat, was introduced into the Holstein and improved their heat tolerance (Olson et al., 2006; Dikmen et al., 2008).

It is noteworthy that Israeli Holsteins have hair coat characteristics close to those of animals possessing the slick gene (Berman, 2004). Marked differences in hair coat thickness and weight $/ 100 \mathrm{~cm}^{2}$ among Holsteins were found between studies carried out in Israel (Berman and Volcani, 1961), Egypt (El Halawany et al., 1984), Iraq (Juma et al., 1986), United States of America (Olson et al., 2006), Brazil (Pinheiro and Silva, 2000), and Australia (Schleger and Turner, 1960a), which probably reflect differences in nutritional and management states. These differences deserve further study.

Overall, the data indicate a dependence of hair coat characteristics on photoperiod, temperature, and nutrition. In the case of hair coat characteristics, but not in the case of sweating, it seems that targeted breeding may offer significant opportunities for improving heat tolerance.

\section{Milk Yield and Heat Stress}

Heat tolerance depends upon the upper and lower critical temperatures that define the thermal comfort range. The upper critical temperature for dairy cows, that above which body temperature starts increasing, was reported as in the 25 to $26^{\circ} \mathrm{C}$ range (Berman et al., 1985) and as 28.4 (Dikmen and Hansen, 2009), which might reflect milk yield differences. The lower critical temperature, that above which thermoregulatory responses start appearing, is highly dependent upon both milk production-related metabolic rate as well as upon hair coat insulation and season (Berman and Meltzer, 1973; Berman, 2004, 2005). A lower metabolic rate may shift the lower critical temperature to higher levels and, thereby, improve heat tolerance (Berman and Meltzer, 1973). In Holstein heifers, a seasonal decline in metabolic rate was evident of similar relative magnitude in both standard and ad libitum-fed cattle. Diurnal variation in metabolic rate was correlated with rectal temperature changes only in the ad libitum-fed animals (Berman, 1968). In high-producing Holsteins in a warm climate, a $23 \%$ seasonal decrease occurred in metabolic rate between early spring and summer, but no ambient temperature-related diurnal variation was evident (Berman and Morag, 1971). Seasonal differences in heat tolerance require time to develop and fade with the passage of seasons. As a whole, these indicate that 
maintenance of high milk production in warm climates is dependent more upon heat stress relief than upon breed type.

Recent studies in the US Holstein population indicated that sufficient genetic variation exists for successful selection for heat tolerance (Misztal and Ravagnolo, 2002). On the other hand, and in line with the aforementioned, bulls that transmitted high tolerance to heat stress had daughters with lower milk yields and higher pregnancy rates, so that continued selection for milk yield may result in greater susceptibility to heat stress (Bohmanova et al., 2005). It seems, therefore, that the dairy industry might benefit from breeding targets modified according to regional climate and heat stress relief management. More specific targets in breeding might become accessible with the introduction of QTL and SNP in breeding programs (Schrooten et al., 2004; Höglund et al., 2009).

\section{Adaptations of Energy Requirements}

It is typical for warm climates, in particular for those located in the subtropical climate zone, that rainfall is seasonal or even scarce. As a result, these regions do not benefit from the continuous growth of plants needed to maintain rapidly-growing and high-producing ruminants. This feature of the environment may have affected cattle breeds during evolution. Cattle that evolved in such regions (e.g., the Zebu and Sanga breeds), might have developed adaptations that enabled them to survive and reproduce in those environments. The nature of these adaptations has not been defined but some clues exist in the literature. A seasonal deficiency of feed supply, as observed in Taiwan (Hwang et al., 2000), prevails in many warm climate regions in which irrigated agriculture is uncommon. In sheep, a lasting decrease in metabolic rate was induced by a period of limited feed intake (Marston, 1948; Merkt and Taylor, 1994). In general, maintenance requirements for weight and energy equilibrium were lower in beef breeds (Angus, Brahman, and Hereford) and their crosses than in dairy breeds (Holstein, Jersey) and their crosses. Efficiency of ME use also favored beef breeds over dairy breeds (Solis et al., 1988). In tropical Mexico, B. indicus of unspecified breed had approximately $10 \%$ lower energy requirements for maintenance than did B. taurus breeds (Cardenas-Medina et al., 2010). However, no difference existed between Nellore and its crosses with Angus, Brown Swiss, and Siemental (de Freitas et al., 2006; de Siqueira et al., 2007). Lower ME requirements were also found in purebred Nellore in Brazil (Calegare et al., 2009). Resting heat production of nonlactating Hariana growing cattle was less than for F1 crosses of Hariana with Holstein, Jersey, or Brown Swiss (Singh and Bhattacharyya, 1985). In Nevada, ME requirements for maintenance were 15 to $25 \%$ smaller in Zebu crossbreeds than in temperate-zone beef breeds (Reid et al., 1991). The lower maintenance energy requirements of Zebu cattle are now widely accepted (NRC, 1996). Lower maintenance requirements leave more nutrients available for growth and milk production when feed is limited, unless these are channeled into adipose tissue depots. A low metabolic rate is linked with puberty and first calving at advanced ages relative to Holstein (i.e., at $\sim 30$ mo and 3-4 yr, respectively, for Zebu breeds in India; Abeygunawardena and Abayawansa, 1995; and $\sim 17$ mo and 3 yr for Zebu breeds in Mexico and South America; Anta et al., 1989; Nogueira, 2004). The benefits of lower energy requirement may, thus, be offset by slower growth rate.

Lower metabolic rate may, however, also be a constitutive characteristic, in which case the metabolic response to increased feed availability may be limited. In this case, such a characteristic, although beneficial in terms of heat tolerance, may decrease the response of animals to improved nutrition. The nature of a lower metabolic rate, whether constitutive or adaptive, may be inferred from the response of such animals to improved environments. The responses of Zebu and Zebu-related cattle to improved environments, including improved health, nutrition, and housing conditions, may be a useful tool for assessing the potential benefit of this characteristic.

\section{Milk Yield Response to Improved Feeding}

Milk yield response to improved environments in Zebu cattle breeds has not been directly studied but indirect evidence is available. Milk yield reported for Sahiwal, Red Sindhi, Gyr, and Hariana cattle on larger farms in India during 1936 to 1950 (Joshi and Phillips, 1953; Mahadevan, 1958) were not much different $50 \mathrm{yr}$ later (Bhadoria et al., 2003; Pundir et al., 2007; Raja and Narula, 2007). Similar responses were observed in Damascus cows, a humpless cattle breed significantly related to the Zebu (Edwards et al., 2007), in which improved nutrition was associated with adipose deposition but little change in milk production (Hirsch and Schindler, 1957). A similar picture emerges from Guzera and Gyr cows in Brazil (Verneque et al., 2000; Ledic et al., 2002). In 51 herds of Gyr cows in Brazil, the mean second to fifth lactation milk yields varied from 2,700 to $4,300 \mathrm{~kg}$, with no clear lactation number effect (Reboucas et al., 2008). Either environmental conditions or genetic production potential may have posed a ceiling to milk yield produced.

The matter may be further assessed by examining milk yield attained by crossing warm-climate cattle to 
cattle of a temperate-climate breed. For Red Sindhi crossbreds with Jersey or Holstein, improved nutrition increased adipose deposition but caused a relatively small increase in milk yield (Branton et al., 1966). A $10 \%$ change in feed allowance for crossbred Holstein $\times$ Vietnamese cattle during early lactation increased BW but not milk yield, which remained at about $10 \mathrm{~kg} / \mathrm{d}$ (Sanh et al., 2002). Increasing feed supply in purebred indigenous Boran (B. indicus) and their crosses with Holsteins increased BCS without having effect on milk yield of purebred cows, whereas in crossbreeds, significant increases in milk yield occurred (Jenet et al., 2004). Purebred Boran cows seem to react to long-term food fluctuations mainly by mobilizing and restoring body fat reserves, whereas cows crossbred with Holsteins tend to spend extra energy preferentially for milk production (Jenet et al., 2006). It seems, therefore, that breeds adapted to warm climates have adopted a strategy favoring fat deposition and a limited increase in milk production. Fat deposition might be advantageous, particularly when ample feed supply is seasonal.

\section{Backcrossing}

Continued backcrossing to a temperate climate breed is of particular interest. In Israel, Damascus cows were crossed back to Friesian for about 10 generations during the formative stage of the Israel dairy herd from 1932 to 1955. Milk recording was initiated in Israel in 1932 and included a gradually increasing number of herds, which allowed examination of continued backcrossing with increasing validity. According to milk recording data of that period, the mean 305-d milk yield in the Damascus cows was $3,180 \mathrm{~kg}$, and changed very little during that period. Crossbreeding increased the milk yield to $3,861 \mathrm{~kg}$ in the first crossbred generation, and ranged between 4,058 to $4,085 \mathrm{~kg}$ in the next 4 subsequent backcrossing generations (i.e., 50 to $6 \%$ Friesian; $\mathrm{n}=1,712$ to 1,800 cows in each generation). The milk yield of Dutch Friesian cows in Israel in 1955 was 4,560 $\mathrm{kg}$ as compared with $5,390 \mathrm{~kg}$ produced in 1955 by US Holsteins imported as pregnant heifers in 1953 (Hojman et al., 2008). The Dutch Friesian and US Holstein share a common origin but the latter was differentiated into a more dairy type. The difference in milk yield is significant enough to suggest that Damascene elements were limiting performance in the first generations of backcrossing to the Holstein, whereas in later stages of herd development, differences between Holstein types were present.

In India, recent reports of milk production in Zebu breeds and Holstein $\times$ Zebu crossbreeds indicate 305-d yields on the order of $2,900 \mathrm{~kg}$, as well as long intercalving periods (Raja and Narula, 2007; Singh et al.,
2007; Lakshmi et al., 2009). Brazilian farmers started in the 1940s to cross Gyr cattle (a B. indicus breed imported from India) with the Holstein. Milk yields of Holstein $\times$ Gyr crosses were 2,574 kg per $305 \mathrm{~d}$ in 4,805 lactation records (Facó et al., 2008), increased with relationship to the Holstein (Barbosa et al., 2008), and were higher than the $1,600 \mathrm{~kg}$ produced by Gyr in India (Joshi and Phillips, 1953). However, increasing the percentage of Holstein improved milk production only in herds with a higher nutrition regimen (Facó et al., 2002). A study of lactation milk yield, 305-d milk yield, lactation length, milk yield per day of lactation, and lifetime milk yield was carried out in Ethiopian Boran cattle and their crosses with Holstein in central Ethiopia. Ethiopian Boran cattle were consistently inferior to the Ethiopian Boran $\times$ Holstein crosses in the dairy traits studied (Haile et al., 2009). In northern Thailand, milk production in Thai $\times$ Friesian crossbred cows was $30 \%$ higher in the $75 \%$ Friesian cows than in the $50 \%$ Friesian $(2,847$ vs. $2,138 \mathrm{~kg})$, but mean milk production in the crossbred was half that of Friesians (Pongpiachan et al., 2000).

As a whole, the aforementioned reports strongly suggest that milk production of warm climate-adapted breeds is inferior to that of imported temperate zone breeds when the gross environmental requirements of the latter, including nutrition, housing, management, and heat stress relief, are supplied to the extent that they permit higher performance. The use of heat stress relief introduces further complexity into the picture, as its effect varies with the stage of lactation in which it is applied (Wolfenson et al., 1988).

Backcrossing a local breed to a higher producing breed is the alternative to import of temperate zone breeds when the provision of gross environmental requirements of the temperate breeds is not feasible. Backcrossing allows a gradual increase in production potential, provided that a concurrent development of the farming system to support production requirements takes place. The success of a backcrossing program depends upon the capacity of the farming system to detect factors limiting performance and on the availability of knowledge, technical facilities, and capital required for correction of limiting factors.

A lower metabolic rate resulting from lower milk production has far-reaching economic consequences on the efficiency of feed utilization for milk production. Using NRC (1996) equations for heat production as a function of milk yield, it is apparent that gross efficiency of milk production for a cow producing $10 \mathrm{~kg}$ of milk (3.5\% fat-corrected) per day is 0.41 , whereas the value for a cow producing $30 \mathrm{~kg}$ is 0.68 . In conditions where water and feed are scarce, a smaller number of higher-producing animals would better utilize existing 
resources as compared with lower-producing ones, concomitant with decreased environment pollution (Capper et al., 2008).

\section{Adaptation of Fertility to Lactation Stress}

Fertility is determined by a chain of physiological events, each of which may be critical for a successful establishment of pregnancy. As such, fertility may be impaired by several factors with high milk production, nutrition and heat stress among them. The interaction between metabolic demands of lactation and the genetic makeup of the cow also can have a negative effect on reproductive function (Chagas, 2007). In the temperate climate of the northern United States, fertility declined over time in Holstein cows, concurrent with a milk yield increase from 4,500 to $7,500 \mathrm{~kg} / 305 \mathrm{~d}$; the decrease in conception rate was associated with the increased recruitment of postpartum body depots for high milk yield synthesis (Butler and Smith, 1989; Huang et al., 2008). Heat stress effects are not necessarily involved in this phenomenon because decreases occurred in the northeastern United States (Butler and Smith, 1989). This phenomenon is present also in crossbred Holstein $\times$ Zebu cattle in spite of lower milk yields of about 2,200 kg (Pongpiachan et al., 2003a). The long calving intervals, 13.5 - to 15 -mo long, in improved breeds in India, Philippines, and Ceylon, contrast with the better reproductive performance of unimproved Zebus, which might be due to their low milk yields (Mahadevan, 1958). Long lactation intervals are reported in recent studies of Zebu breeds and their crosses with Holstein (Pundir and Singh, 2007; Raja and Narula, 2008) in India and in northern Thailand (Pongpiachan et al., 2003a,b), and may reflect nutritional deficiencies even at relatively low milk production.

No obvious effect of breed on this phenomenon exists. A study was carried out on Guzerat (B. indicus) in Brazil, yielding 840 to $4,850 \mathrm{~kg} / 305 \mathrm{~d}$ of lactation. A significant part of this breed was formed in Brazil by backcrossing native females of $B$. taurus origin with Guzerat bulls imported from India. Breeding values for lactation yields, age at first calving, and calving interval over the period from 1971 to 2006 did not differ between the $B$. indicus $(\mathrm{n}=504)$ and the $B$. taurus $(\mathrm{n}=205)$ maternal lineage groups. In both groups, an inverse relationship existed between production and reproductive performance indices, similar to that found in the Holstein (Paneto et al., 2008). Evidence that this relationship is dependent upon relative milk yield and not upon breed was also found in Thai $\times$ Friesian and Friesian cows (Pongpiachan et al., 2003b). Similarly, in Gyr (B. indicus), Holstein, and their crossbreeds in Brazil (Guimãraes et al., 2002), reproductive function was not related to genetic background or milk production between 1,500 to 4,200 kg per lactation.

The unequivocal relationships between fertility and milk production for cattle of the 2 origins supports the view that the phenomenon is not breed dependent but reflects breed-independent factors. If Zebu breeds are representative of warm-climate adapted animals, then heat adaptation did not markedly decrease the effect of milk yield on fertility. The possibility that this relationship might have a genetic component cannot be excluded, however. The large genetic variability in $B$. indicus (Murray et al., 2010) might tentatively offer a possibility for dissociating milk yield and fertility.

\section{Adaptation of Fertility to Heat Stress}

Heat stress effects on reproduction are typically expressed as difficulties in estrus detection and death of embryos at early stages of pregnancy. No evidence has been found to indicate a better manifestation of estrous behavior in $B$. indicus breeds, which would enable more efficient detection of estrus. Estrus detection difficulties have been alleviated by development of timed AI programs that allow insemination independently of estrus detection (Hansen and Aréchiga, 1999; Thatcher et al., 2006). An increased sensitivity of estrus detection by monitoring of physical activity is available in technologically-advanced farming systems (Løvendahl and Chagunda, 2010). This technology might assist in estrus detection, particularly when cows are allocated space large enough and flooring adequate for free expression of behavioral estrus.

Breed differences in resistance to heat stress at early stages of pregnancy may have marked effects on reproduction outcome. Assessing the presence of breed differences in response of fertility to heat stress is made complex by the effects of time of heat stress relative to fertilization, and by probable lactation effects on fertility response to heat stress. The relative role played by maternal and paternal factors also is unknown and adds further complexity to the matter.

In lactating Holstein cows, heat stress decreased embryo viability and development when imposed on the cows on $\mathrm{d} 1$ of pregnancy but not on later days (Ealy et al., 1993). A study of in vitro fertilized oocytes aspirated from nonlactating Holstein and Gyr cows in the warm climate of Brazil indicated a higher cleavage (on d 3) and blastocyst rates (on d 7) in cultured embryos of Gyr cows, but no breed differences in pregnancy rates following transfer of blastocysts to recipients (Camargo et al., 2007). These studies suggest that a breed effect might be restricted to the early pre-implantation stage, as heat stress was present in early as well as in later pregnancy stages. Such differences might be 
related to the transition from maternal transcription to zygotic transcription during this stage (Memili and First, 2000), the role of which might be partly clarified by reciprocal crosses. Further resolution has been reached in studies that focused on the early pre-implantation stage. In nonlactating Brahman and Holstein cows, heat exposure at the 2 to 4 cell stage, before the embryonic genome was fully activated, decreased the proportion of embryos that developed to blastocyst stage but no breed differences were detectable, possibly owing to small numbers (Krininger et al., 2003). The exposure of in vitro cultured embryos to $41^{\circ} \mathrm{C}$ for $6 \mathrm{~h}$ at $5 \mathrm{~d}$ after insemination (after genome activation; Memili and First, 2000; Minami et al., 2007), decreased development to the blastocyst stage and the number of cells per embryo; effects were less deleterious for Brahman and Senepol embryos (2 thermotolerant breeds) than for Angus and Holstein embryos (non-thermotolerant breeds; Paula-Lopes et al., 2003). Embryos, 4 d after in vitro fertilization, from nonlactating Brahman and Romosinuano cows were more resistant to heat stress than were embryos from Angus cows (Hernández-Cerón et al., 2004). A similar experimental approach was used in comparing Nelore (B. indicus) embryos with Nelore $\times B$. taurus crossbreed embryos (B. taurus oocytes fertilized with Nelore semen). Nelore embryos were more resistant to heat shock than were crossbreed embryos at an early stage (9 to $12 \mathrm{~h}$ post fertilization), but not at a late stage ( 48 to $80 \mathrm{~h}$ post fertilization) of in vitro development. This did not seem to be an additive characteristic, as the resistance of Nelore embryos to heat shock was similar to that of embryos from crossbreed oocytes fertilized with Nelore spermatozoa (Monteiro et al., 2007). Possible effects of lactation on the tentative breed effects on fertility are suggested by a study that compared lactating Gyr and Holstein cows at about 200 d postpartum, in which no significant difference between breeds was found in summer conception rates $(>\sim 10 \%)$ or in embryo losses (Pegorer et al., 2007). In the latter study, higher milk yield was associated with lower within-breed conception rates.

The in vitro fertilization approach might be used to bypass embryonic losses due to heat stress by culturing embryos at normal temperatures before their introduction in the uteri of recipient cows. Its use for improving fertility in warm weather and climates depends, however, upon changes in the present dairy farming system.

The aforementioned studies leave unanswered some questions that might mask tentative effects of breeds. They were carried out on oocytes obtained from nonlactating cows, excepting but 2 studies (Ealy et al., 1993; Pegorer et al., 2007). It is possible, though, that lactation may alter oocyte competence or affect breed differences. An effect of lactation has to be considered, in light of the marked negative effect of milk yield on reproduction efficiency (Butler and Smith, 1989; Huang et al., 2008). Embryo culture systems do not allow full expression of effects of conditions prevailing in the oviduct and uterus during early pregnancy that affect embryo competence. The importance of genome activation in the expression of breed differences in resistance to heat has also yet to be defined.

In summary, data point to the presence of genetic differences in embryo sensitivity to heat stress. Genetic differences in heat tolerance, attributed to sire differences independent of breed (Bohmanova et al., 2005), need further evaluation for their potential effect in decreasing the effects of heat stress on reproduction efficiency.

\section{CONCLUSIONS}

The overall picture emerging from this overview does not lend support to the notion that breeds which evolved in warm climates (e.g., the $B$. indicus and $B$. taurus Sanga types), share attributes that endow them with higher capacity for heat dissipation. The possible exception to this conclusion may be for respiratory heat loss, for which little evidence exists either way. With the exception of the slick hair gene, hair coat attributes in warm climates largely reflect effects of nutrition, management, and climate during the animals' lifetime, rather than differences in genetic constitution.

In $B$. indicus, a negative relationship between milk production and fertility is evident. This relationship, which is similar to that in B. taurus but at much lower milk production and feed intake, supports the view that decreased fertility at higher relative milk yields reflects effects of nutritional deficiency. However, the possibility cannot be excluded that this relationship is induced by an interaction between lactation and reproduction that is shared by the 2 types of cattle.

The finding that embryos of $B$. indicus origin may tolerate high temperatures, if substantiated by further studies, is of particular interest because it suggests an extension of normal function to a temperature range considered as hyperthermic for cattle.

Solid evidence exists for a lower maintenance requirement and lower milk production capacity in Zebu breeds, or their F1 crosses, with little response to improved nutrition. These characteristics, when coupled with tick resistance, probably form the basis of the improved capacity of these breeds to tolerate warm climate conditions. Lower productivity, however, decreases efficiency of feed utilization. This decrease is of particular importance when resources are limited. The need for cattle to serve as draft animals can con- 
tradict the rationale of using high-producing animals in farming systems depending on animal power. The highproducing animals may serve in technology-supported farming systems in which thermal stress may be alleviated by appropriate means.

The notion that certain breeds are adapted to warm climates should be widened to consider not only thermal attributes of climate but also their interactions with farming system and animal characteristics. A climate-oriented farming system would benefit by setting a productivity goal and complementing animals' homeostatic capacity with socioeconomically feasible technologies to alleviate climate stress so as to meet the desired productivity.

\section{REFERENCES}

Abeygunawardena, H., and W. D. Abayawansa. 1995. Studies on indigenous Zebu cattle. 1. Reproductive pattern under traditional management. J. Natl. Sci. Counc. Sri Lanka 23:131-142.

Aggarwal, A., and R. C. Upadhyay. 1997. Pulmonary and cutaneous evaporative water losses in Sahiwal and Sahiwal $\times$ Holstein cattle during solar exposure. Asian-australas. J. Anim. Sci. 10:318323.

Anta, E., J. A. Rivera, C. Galina, A. Porras, and L. Zarco. 1989. Analysis of work published in Mexico on the reproductive performance of cattle. 2. Reproductive traits. Veterinaria (Mex) 20:11-18.

Barbosa, S. B. P., R. P. Ramalho, H. G. Monardes, F. M. Dias, D. C. dos Santos, and A. M. V. Batista. 2008. Milk and fat production of crossbred Holstein-Gir cows (Bos taurus taurus-Bos taurus indicus) in the Agreste region of the Brazilian state of Pernambuco. Genet. Mol. Biol. 31:468-474.

Bennett, J. W. 1964. Thermal insulation of cattle coats. Proc. Aust. Soc. Anim. Prod. 5:160-166.

Berman, A. 1957. Influence of some factors on the relative evaporation rate from the skin of cattle. Nature 179:1256.

Berman, A. 1968. Nychthemeral and seasonal patterns of thermoregulation in cattle. Aust. J. Agric. Res. 19:181-189.

Berman, A. 2004. Tissue and external insulation estimates and their effects on prediction of energy requirements and of heat stress. J. Dairy Sci. 87:1400-1412.

Berman, A. 2005. Estimates of heat stress relief needs for Holstein dairy cows. J. Anim. Sci. 83:1377-1384.

Berman, A. 2008. Increasing heat stress relief produced by coupled coat wetting and forced ventilation. J. Dairy Sci. 91:4571-4578.

Berman, A. 2009. Predicted limits for evaporative cooling in heat stress relief of cattle in warm conditions. J. Anim. Sci. 87:3413-3417.

Berman, A., Y. Folman, M. Kaim, M. Mamen, Z. Herz, D. Wolfenson, A. Arieli, and Y. Graber. 1985. Upper critical temperatures and forced ventilation effects for high-yielding cows in a subtropical climate. J. Dairy Sci. 68:1488-1495.

Berman, A., and A. Meltzer. 1973. Critical temperatures in lactating dairy cattle: A new approach to an old problem. Int. J. Biometeorol. 17:167-176.

Berman, A., and M. Morag. 1971. Nychthemeral patterns of thermoregulation in high-yielding cows in a hot dry near-natural climate. Aust. J. Agric. Res. 22:671-680.

Berman, A., and R. Volcani. 1961. Seasonal and regional variations in coat characteristics of dairy cattle. Aust. J. Agric. Res. 12:528538.

Bhadoria, H. B. S., F. H. Khan, S. S. Tomar, and M. C. Yadav. 2003. Sources of variation in production traits and phenotypic and genetic correlations among themselves in Gir cattle. Indian J. Anim. Sci. 73:1256-1259.

Black, S. J., J. R. Seed, and N. B. Murphy. 2001. Innate and acquired resistance to African trypanosomiasis. J. Parasitol. 87:1-9.
Bock, R. E., and A. J. de Vos. 2001. Immunity following use of australian tick fever vaccine: A review of the evidence. Aust. Vet. J. 79:832-839.

Bock, R. E., T. G. Kingston, and A. J. De Vos. 1999. Effect of breed of cattle on innate resistance to infection with Anaplasma marginale transmitted by Boophilus microplus. Aust. Vet. J. 77:748-751.

Bohmanova, J., I. Misztal, S. Tsuruta, D. Norman, and T. J. Lawlor. 2005. National genetic evaluation of milk yield for heat tolerance of United States Holsteins. Interbull Bull. 33:160-162.

Branton, C., R. E. McDowell, and M. A. Brown. 1966. Zebu-European crossbreeding as a basis of dairy cattle improvement in the U.S.A. in Southern Coop. Ser. Bull. 114. Louisiana State Univ., Baton Rouge.

Butler, W. R., and R. D. Smith. 1989. Interrelationships between energy balance and postpartum reproductive function in dairy cattle. J. Dairy Sci. 72:767-783.

Calegare, L., M. M. Alencar, I. U. Packer, C. L. Ferrell, and D. P. D. Lanna. 2009. Cow/calf preweaning efficiency of Nellore and Bos taurus $\times$ Bos indicus crosses. J. Anim. Sci. 87:740-747.

Camargo, L. S. A., J. H. M. Viana, A. A. Ramos, R. V. Serapião, W. F. de Sa, A. M. Ferreira, M. F. M. Guimarães, and V. R. do Vale Filho. 2007. Developmental competence and expression of the Hsp 70.1 gene in oocytes obtained from Bos indicus and Bos taurus dairy cows in a tropical environment. Theriogenology 68:626-632.

Capper, J. L., E. Castañeda-Gutiérrez, A. Cady, and D. E. Bauman. 2008. The environmental impact of recombinant bovine somatotropin (rbST) use in dairy production. Proc. Natl. Acad. Sci. USA 105:9668-9673.

Cardenas-Medina, J. V., J. C. Ku-Vera, and J. G. Magana-Monforte. 2010. Estimation of metabolizable energy requirements for maintenance and energetic efficiency of weight gain in Bos taurus and Bos indicus cows in tropical Mexico. J. Anim. Vet. Adv. 9:421-428.

Chagas, L. M., J. J. Bass, D. Blache, C. R. Burke, J. K. Kay, D. R. Lindsay, M. C. Lucy, G. B. Martin, S. Meier, F. M. Rhodes, J. R. Roche, W. W. Thatcher, and R. Webb. 2007. Invited review: New perspectives on the roles of nutrition and metabolic priorities in the subfertility of high-producing dairy cows. J. Dairy Sci. 90:4022-4032.

Dani, M. A. C., M. B. Heinneman, and S. U. Dani. 2008. Brazilian Nelore cattle: A melting pot unfolded by molecular genetics. Genet. Mol. Res. 7:1127-1137.

de Freitas, J. A., A. C. de Queiroz, A. R. Dutra, R. A. M. Vieira, R. D. Lana, F. D. Leonel, D. S. Henrique, A. V. de Lima, and J. C. de Souza. 2006. Body composition and net energy requirements for maintenance of feedlot purebred and crossbred Nellore young bulls. R. Bras. Zootec. 35:878-885.

de Siqueira, J. G., C. A. D. Fontes, A. L. Pereira, C. T. Lombardi, N. D. S. Ana, and R. A. M. Vieira. 2007. Maintenance energy requirements and body and gain composition of adults beef cows from three genetic groups. R. Bras. Zootec. 36:2159-2167.

Dikmen, S., E. Alava, E. Pontes, J. M. Fear, B. Y. Dikmen, T. A. Olson, and P. J. Hansen. 2008. Differences in thermoregulatory ability between slick-haired and wild-type lactating Holstein cows in response to acute heat stress. J. Dairy Sci. 91:3395-3402.

Dikmen, S., and P. J. Hansen. 2009. Is the temperature-humidity index the best indicator of heat stress in lactating cows in a subtropical environment? J. Dairy Sci. 92:109-116.

Dowling, D. F. 1955. The hair follicle and apocrine gland populations of Zebu (Bos indicus L.) and shorthorn (B. taurus L.) cattle skin. Aust. J Agric. Sci. 6:645-654.

Ealy, A. D., M. Drost, and P. J. Hansen. 1993. Developmental changes in embryonic resistance to adverse effects of maternal heat stress in cows. J. Dairy Sci. 76:2899-2905.

Edwards, C. J., J. F. Baird, and D. E. MacHugh. 2007. Taurine and Zebu admixture in near eastern cattle: A comparison of mitochondrial, autosomal and y-chromosomal data. Anim. Genet. 38:520524

Egbunike, G. N., A. L. Ogunmola, and S. F. Amakiri. 1983. The relative influence of temperature and humidity on cutaneous func- 
tion in Bos indicus and Bos taurus females. Int. J. Biometeorol. $27: 235-248$

El Halawany, R. S., M. El Fateh, I. Salem, R. S. E. Halawany, and M. E. Fateh. 1984. Skin and hair characteristics of Friesian and Jersey cows as affected by age, season of the year and their relation with milk production. Assiut Vet. Med. J. 11:35-40.

Facó, O., R. N. B. Lôbo, R. Martins Filho, G. A. Martins, S. M. P. de Oliveira, and D. M. Machado Ribeiro Azevêdo. 2008. Additive and non-additive genetic effects on productive and reproductive traits in Holstein $\times$ Gir crossbred cows. R. Bras. Zootec. 37:48-53.

Facó, O., R. N. B. Lôbo, R. Martins Filho, and A. D. A. Moura. 2002. Analysis of productive performance of different Holstein $\times$ Gir genetic groups in Brazil. R. Bras. Zootec. 31:1944-1952.

Fivaz, B. H., D. T. de Waal, and K. Lander. 1992. Indigenous and crossbred cattle - A comparison of resistance to ticks and implications for their strategic control in Zimbabwe. Trop. Anim. Health Prod. 24:81-89.

Flamenbaum, I., D. Wolfenson, M. Mamen, and A. Berman. 1986 Cooling dairy cattle by a combination of sprinkling and forced ventilation and its implementation in the shelter system. J. Dairy Sci. 69:3140-3147

Frisch, J. E., C. J. O'Neill, and M. J. Kelly. 2000. Using genetics to control cattle parasites - The Rockhampton experience. Int. J. Parasitol. 30:253-264.

Gaughan, J. B., T. L. Mader, S. M. Holt, M. J. Josey, and K. J. Rowan. 1999. Heat tolerance of Boran and Tuli crossbred steers. J. Anim. Sci. 77:2398-2405.

Gebremedhin, K. G., C. N. Lee, P. E. Hillman, and R. J. Collier. 2010. Physiological responses of dairy cows during extended solar exposure. Trans. ASABE 53:239-247.

Glass, E. J., P. M. Preston, A. Springbett, S. Craigmile, E. Kirvar, G. Wilkie, and C. G. Duncan Brown. 2005. Bos taurus and Bos indicus (Sahiwal) calves respond differently to infection with Theileria annulata and produce markedly different levels of acute phase proteins. Int. J. Parasitol. 35:337-347.

Guimãraes, J. D., N. G. Alves, E. P. da Costa, M. R. Silva, F. M. J. Costa, and B. Zamperlini. 2002. Reproductive and productive efficiencies in Holstein and Holstein $\times$ Zebu cows crossbreds. $\mathrm{R}$. Bras. Zootec. 31:641-647.

Haile, A., B. K. Joshi, W. Ayalew, A. Tegegne, and A. Singh. 2009. Genetic evaluation of Ethiopian Boran cattle and their crosses with Holstein Friesian in central Ethiopia: Milk production traits. Animal 3:486-493.

Hansen, P. J., and C. F. Aréchiga. 1999. Strategies for managing reproduction in the heat-stressed dairy cow. J. Anim. Sci. 77(Suppl. $2): 36-50$.

Hayman, R. H., and T. Nay. 1958. Sweat glands in Zebu (Bos indicus L.) and European (B. taurus L.) cattle. II. Effects of season and exercise on sweat gland volume. Aust. J Agric. Sci. 9:385-390.

Hayman, R. H., and T. Nay. 1961. Observations on hair growth and shedding in cattle. Aust. J. Agric. Res. 12:513-527.

Hernández-Cerón, J., C. C. Chase Jr., and P. J. Hansen. 2004. Differences in heat tolerance between preimplantation embryos from Brahman, Romosinuano, and Angus breeds. J. Dairy Sci. 87:5358.

Hirsch, S., and H. Schindler. 1957. The Syrian and Dutch Friesian cattle and their crosses in Israel. Ktavim Rec. Agric. Res. Sta. Gov. 7:1-40.

Höglund, J. K., A. J. Buitenhuis, B. Guldbrandtsen, G. Su, B. Thomsen, and M. S. Lund. 2009. Overlapping chromosomal regions for fertility traits and production traits in the Danish Holstein population. J. Dairy Sci. 92:5712-5719.

Hojman, D., Y. Malul, and T. Avrech. 2008. The dairy industry in Israel. Israel Cattle Breeders Assoc., 38900 Caesaria Industrial Park, Israel.

Huang, C., S. Tsuruta, J. K. Bertrand, I. Misztal, T. J. Lawlor, and J. S. Clay. 2008. Environmental effects on conception rates of Holsteins in New York and Georgia. J. Dairy Sci. 91:818-825.
Hwang, S. Y., M. J. Lee, and P. W. S. Chiou. 2000. Monitoring nutritional status of dairy cows in Taiwan using milk protein and milk urea nitrogen. Asian-australas. J. Anim. Sci. 13:1667-1673.

Jenet, A., S. Fernandez-Rivera, A. Tegegne, H. R. Wettstein, M. Senn, M. Saurer, W. Langhans, and M. Kreuzer. 2006. Evidence for different nutrient partitioning in Boran (Bos indicus) and Boran $\times$ Holstein cows when re-allocated from low to high or from high to low feeding level. J. Vet. Med. A Physiol. Path. Clin. Med. 53:383-393.

Jenet, A., A. Yimegnuhal, S. Fernandez-Rivera, A. Tegegne, P. O. Osuji, G. McCrabb, and M. Kreuzer. 2004. Long-term response to feeding level in lactational performance of Boran (Bos indicus) and Boran $\times$ Holstein cows. Anim. Sci. 78:331-343.

Jonsson, N. N., R. E. Bock, and W. K. Jorgensen. 2008. Productivity and health effects of anaplasmosis and babesiosis on Bos indicus cattle and their crosses, and the effects of differing intensity of tick control in Australia. Vet. Parasitol. 155:1-9.

Joshi, B. C., R. E. McDowell, and D. P. Sadhu. 1968. Surface evaporation from the normal body surface and with sweat glands inactivated in Indian cattle. J. Dairy Sci. 51:915-917.

Joshi, N. R., and R. W. Phillips. 1953. Zebu Cattle of India and Pakistan. FAO Agricultural Studies, No. 19. Food and Agriculture Organization of the United Nations, Rome, Italy.

Juma, K. H., J. E. Alkass, and D. A. Aziz. 1986. Study of some coat characteristics of Friesian and native cattle in Iraq. Iraqi J. Agric. Sci. Zanco 4:7-12.

Kadarmideen, H. N., B. de Klerk, and K. C. Prayaga. 2009. Evidence of a major gene for tick and worm resistance in tropical beef cattle via complex segregation analyses. Proc. 60th EAAP Annual Meeting, Barcelona, Spain. Wageningen Academic Publishers, Wageningen, the Netherlands

Kibler, H. H., H. D. Johnson, M. D. Shanklin, and L. Hahn. 1965. Environmental physiology and shelter engineering. LXIX. Acclimation of Holstein cattle to $29^{\circ} \mathrm{C}$ temperature: Changes in heat production and heat dissipation functions. Univ. Missouri Agric. Expt. Sta. Res. Bull 893, Columbia, MO.

Krininger, C. E., J. Block, Y. M. Al-Katanani, R. M. Rivera, C. C. Chase, and P. J. Hansen. 2003. Differences between Brahman and Holstein cows in response to estrus synchronization, superovulation and resistance of embryos to heat shock. Anim. Reprod. Sci. $78: 13-24$.

Lakshmi, B., B. Ramesh Gupta, K. Sudhakar, M. Gnana Prakash, and S. Sharma. 2009. Genetic analysis of production performance of Holstein Friesian $\times$ Sahiwal cows. Tamilnadu J. Vet. Anim. Sci. 5:143-148.

Ledic, I. L., R. D. Verneque, L. El Faro, H. Tonhati, M. L. Martinez, M. D. S. de Oliveira, C. N. Costa, R. L. Teodoro, and L. D. O. Fernandes. 2002. Genetic evaluation of Gir breed sires for milk production at the control day and 305 days of lactation. R. Bras. Zootec. 31:1964-1972.

Loftus, R. T., O. Ertugrul, A. H. Harba, M. A. A. El-Barody, D. E. MacHugh, S. D. E. Park, and D. G. Bradley. 1999. A microsatellite survey of cattle from a centre of origin: The Near East. Mol. Ecol. 8:2015-2022.

Løvendahl, P., and M. G. G. Chagunda. 2010. On the use of physical activity monitoring for estrus detection in dairy cows. J. Dairy Sci. 93:249-259.

Mahadevan, P. 1958. Dairy Cattle Breeding in the Tropics. CAB, Farnham Royal, Bucks, UK.

Maia, A. S. C., R. G. daSilva, and C. M. Battiston Loureiro. 2005. Sensible and latent heat loss from the body surface of Holstein cows in a tropical environment. Int. J. Biometeorol. 50:17-22.

Marston, H. R. 1948. Energy transactions in the sheep. Aust. J. Sci Res., B 1:93-104.

Mattioli, R. C., V. S. Pandey, M. Murray, and J. L. Fitzpatrick. 2000 Immunogenetic influences on tick resistance in African cattle with particular reference to trypanotolerant N'Dama (Bos taurus) and trypanosusceptible Gobra Zebu (Bos indicus) cattle. Acta Trop. 75:263-277. 
McDowell, R. E., D. H. K. Lee, and M. H. Fohrman. 1954. The measurement of water evaporation from limited areas of a normal body surface. J. Anim. Sci. 13:405-416.

McLean, J. A. 1963. Partition of insensible losses of body weight and heat from cattle under various climatic conditions. J. Physiol. 167:427-447.

McManus, C., E. Prescott, G. R. Paludo, E. Bianchini, H. Louvandini, and A. S. Mariante. 2009. Heat tolerance in naturalized Brazilian cattle breeds. Livest. Sci. 120:256-264.

Memili, E., and N. L. First. 2000. Zygotic and embryonic gene expression in cow: A review of timing and mechanisms of early gene expression as compared with other species. Zygote 8:87-96.

Merkt, J. R., and C. R. Taylor. 1994. Metabolic switch for desert survival. Proc. Natl. Acad. Sci. USA 91:12313-12316.

Minami, N., T. Suzuki, and S. Tsukamoto. 2007. Zygotic gene activation and maternal factors in mammals. J. Reprod. Dev. 53:707715 .

Misztal, I., and O. Ravagnolo. 2002. Studies on genetics of heat tolerance in Holsteins. Proc 7th World Congress on Gen. Appl. Livestock Prod., Montpellier, France 18:1-4. Event Lab. GmbH, Leipzig, Germany.

Monteiro, F. M., E. C. Freitas, D. S. Melo, L. M. Carvalho, A. B. Teixeira, L. A. Coelho, L. A. Trinca, and C. M. Barros. 2007. Resistance of embryos from Bos indicus cattle during early stages of in vitro development to heat shock compared to embryos crossbred from crossbred cattle. Anim. Reprod. 4:51-58.

Murray, C., E. Huerta-Sanchez, F. Casey, and D. G. Bradley. 2010. Cattle demographic history modelled from autosomal sequence variation. Phil. Trans. R. Soc. B 365:2531-2539.

Nay, T., and R. H. Hayman. 1956. Sweat glands in Zebu (B. indicus) and European cattle (B. taurus) cattle. Aust. J. Agric. Res. $7: 482-492$.

Nay, T., and R. H. Hayman. 1963. Some skin characters in five breeds of European (Bos taurus) dairy cattle. Aust. J. Agric. Res. 14:294-302

Nogueira, G. P. 2004. Puberty in South American Bos indicus (Zebu) cattle. Anim. Reprod. Sci. 82-83:361-372.

NRC. 1996. Nutrient Requirements of Beef Cattle. 7th rev. ed. Page 6. Natl. Acad. Sci., Washington, DC.

Olson, T. A., C. C. Chase Jr., C. Lucena, E. Godoy, A. Zuniga, and R. J. Collier. 2006. Effect of hair characteristics on the adaptation of cattle to warm climates. Proc. 8th World Cong. Gen. Appl. Livestock. Prod. Belo Horizonte, Minas Gerais, Brazil 16-07.

Olson, T. A., C. Lucena, C. C. Chase, and A. C. Hammond. 2003. Evidence for a major gene influencing hair length and heat tolerance in Bos taurus cattle. J. Anim. Sci. 81:80-90.

Pan, Y. S., S. M. Donegan, and R. H. Hayman. 1969. Sweating rate at different body regions in cattle and its correlation with some quantitative components of sweat gland volume for a given area of skin. Aust. J. Agric. Res. 20:395-403.

Paneto, J. C. C., J. B. S. Ferraz, J. C. C. Balieiro, J. F. F. Bittar, M. B. D. Ferreira, M. B. Leite, G. K. F. Merighe, and F. V. Meirelles. 2008. Bos indicus or Bos taurus mitochondrial DNA - Comparison of productive and reproductive breeding values in a Guzerat dairy herd. Genet. Mol. Res. 7:592-602.

Paula-Lopes, F. F., C. C. Chase Jr., Y. M. Al-Katanani, C. E. Krininger 3rd, R. M. Rivera, S. Tekin, A. C. Majewski, O. M. Ocon, T. A. Olson, and P. J. Hansen. 2003. Genetic divergence in cellular resistance to heat shock in cattle: Differences between breeds developed in temperate versus hot climates in responses of preimplantation embryos, reproductive tract tissues and lymphocytes to increased culture temperatures. Reproduction 125:285-294.

Pegorer, M. F., J. L. M. Vasconcelos, L. A. Trinca, P. J. Hansen, and C. M. Barros. 2007. Influence of sire and sire breed (Gyr versus Holstein) on establishment of pregnancy and embryonic loss in lactating Holstein cows during summer heat stress. Theriogenology $67: 692-697$

Pinheiro, M. D., and R. G. da Silva. 2000. Season of the year and hair coat characteristics of Holstein cows. Bol. Ind. Anim. 57:99-103.
Pinheiro, M. D., and R. G. da Silva. 1998. Hair coat characteristics and production of Holstein cows in tropical environment. I. Hair coat traits. Bol. Ind. Anim. 55:1-6.

Pongpiachan, P., P. Rodtian, and K. Ota. 2000. Lactation in crossand purebred Friesian cows in northern Thailand and analyses on effects of tropical climate on their lactation. Asian-australas. J. Anim. Sci. 13:1316-1322.

Pongpiachan, P., P. Rodtian, and K. Ota. 2003a. Effects of tropical climate on reproduction of cross- and purebred Friesian cattle in northern Thailand. Asian-australas. J. Anim. Sci. 16:952-961.

Pongpiachan, P., P. Rodtian, and K. Ota. 2003b. Reproduction of cross- and purebred Friesian cattle in northern Thailand with special reference to their milk production. Asian-australas. J. Anim. Sci. 16:1093-1101.

Pundir, R., P. Singh, S. Upadhaya, and S. Ahlawat. 2007. Status, characteristics and performance of Red Sindhi cattle. Indian J. Anim. Sci. 77:755-758.

Pundir, R. K., and K. Singh. 2007. Estimates of genetic parameters and trends of various performances traits of Red Sindhi cattle using single trait animal model. Indian J. Anim. Sci. 77:1002-1006.

Raja, K., and H. Narula. 2007. Effects of non-genetic factors on production traits of Sahiwal cattle. Indian Vet. J. 84:374-376.

Raja, K., and H. Narula. 2008. Non-genetic factors influencing reproductive performance traits in Sahiwal cattle. Indian Vet. J. 85:213-214.

Rasulov, I., L. Fish, and V. Shkap. 2008. Vaccination of cattle against tropical theileriosis in Uzbekistan using autochthonous live vaccine. Vaccine 26:G14-G16.

Reboucas, G. F., T. D. Goncalves, M. L. Martinez, J. Azevedo, and W. J. Koops.. 2008. New functions to estimate 305-days milk production of Gir cows. R. Bras. Zootec. 37:1222-1229.

Reid, C. R., C. M. Bailey, and M. B. Judkins. 1991. Metabolizable energy for maintenance of beef-type Bos taurus and Bos indicus $\times$ Bos taurus cows in a dry, temperate climate. J. Anim. Sci. 69:2779-2786.

Sanh, M. V., H. Wiktorsson, and L. V. Ly. 2002. Effect of feeding level on milk production, body weight change, feed conversion and postpartum oestrus of crossbred lactating cows in tropical conditions. Livest. Prod. Sci. 77:331-338.

Scharf, B., J. A. Carroll, D. G. Riley, C. C. Chase, S. W. Coleman, D. H. Keisler, R. L. Weaber, and D. E. Spiers. 2010. Evaluation of physiological and blood serum differences in heat-tolerant (Romosinuano) and heat-susceptible (Angus) Bos taurus cattle during controlled heat challenge. J. Anim. Sci. 88:2321-2336.

Scharf, B., L. E. Wax, G. E. Aiken, and D. E. Spiers. 2008. Regional differences in sweat rate response of steers to short-term heat stress. Int. J. Biometeorol. 52:725-732.

Schleger, A. V., and H. G. Turner. 1960a. Analysis of coat characters of cattle. Aust. J. Agric. Res. 11:875-885.

Schleger, A. V., and H. G. Turner. 1960b. The significance of coat type in cattle. Aust. J. Agric. Res. 11:645-663.

Schleger, A. V., and H. G. Turner. 1965. Sweating rates of cattle in field and their reaction to diurnal and seasonal changes. Aust. J. Agric. Res. 16:92-106.

Schrooten, C., M. C. A. M. Bink, and H. Bovenhuis. 2004. Whole genome scan to detect chromosomal regions affecting multiple traits in dairy cattle. J. Dairy Sci. 87:3550-3560.

Singh, K., and N. K. Bhattacharyya. 1985. Resting heat production in Bos indicus and their F1 crosses with exotic breeds at a thermoneutral environment. Br. J. Nutr. 53:301-305.

Singh, P. K., G. K. Gaur, R. K. Pundir, and A. Singh. 2007. Characterization and evaluation of Gangatiri cattle breed in its native tract. Indian J. Anim. Sci. 77:66-70.

Solis, J. C., F. M. Byers, G. T. Schelling, C. R. Long, and L. W. Greene. 1988. Maintenance requirements and energetic efficiency of cows of different breed types. J. Anim. Sci. 66:764-773.

Thatcher, W. W., T. R. Bilby, J. A. Bartolome, F. Silvestre, C. R. Staples, and J. E. P. Santos. 2006. Strategies for improving fertility in the modern dairy cow. Theriogenology 65:30-44. 
Vajrabukka, C., and C. J. Thwaites. 1984. The relative influences of exercise and coat-type on the thermoregulatory responses of cattle. Int. J. Biometeorol. 28:9-15.

Verissimo, C. J., C. V. J. Nicolau, V. L. Cardoso, and M. G. Pinheiro, 2002. Haircoat characteristics and tick infestation on Gir (Zebu) and crossbred (Holstein $\times$ Gir) cattle. Arch. Zootec., Córdoba $51: 389-392$.

Verneque, R. D., M. L. Martinez, and R. L. Teodoro. 2000. Cow and sire genetic evaluation from Gyr breed based on partial records of milk production. R. Bras. Zootec. 29:1060-1066.
Wolfenson, D., I. Flamenbaum, and A. Berman. 1988. Dry period heat stress relief effects on prepartum progesterone, calf birth weight and milk production. J. Dairy Sci. 71:809-818.

Wright, N. C. 1954. The ecology of domesticated animals. Pages 191251 in Progress in the physiology of farm animals. Vol. 1. J. Hammond, ed. Butterworths Pub., Ltd., London, UK.

Yeates, N. T. M. 1954. Environmental control of coat changes in cattle. Nature 174:609-610.

Yeates, N. T. M. 1956. Influence of nutritional state on the heat tolerance of cattle. Nature 178:702-703. 